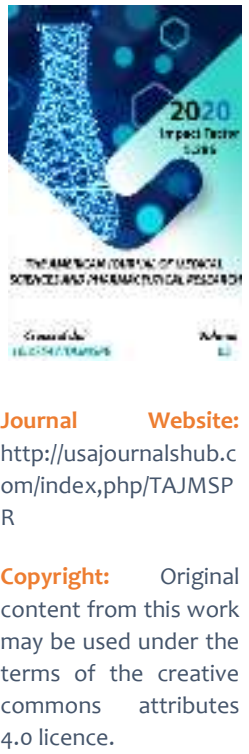

\section{Comparative Analysis Of The Electrophysiological Indicators Of The Optic Nerve In Complex Treatment Of Patients With Primary Open-Angle Glaucoma}

\author{
Abulkasimova Kh.Kh. \\ Ophthalmologist In The Central Polyclinic Of Mirabad District, Tashkent, Uzbekistan
}

Karimova M.Kh.

Doctor Of Medical Sciences, Professor, Deputy Director For Scientific Work Of The Republican Specialized Center Of Eye Microsurgery, Tashkent, Uzbekistan

Zakirkhodjayeva M.A.

Ophthalmologist In The Republican Specialized Center Of Eye Microsurgery, Tashkent, Uzbekistan

\title{
ABSTRACT
}

Despite significant progress achieved with the help of local medical, surgical and laser treatment, primary open-angle glaucoma (POAG) remains an actual issue in ophthalmology due to incurable blindness and disability

\section{KEYWORDS}

Structural components, clinical material, fusion of flickers, ultrastructural components, neurotransmission in the optic nerve, the dynamics of CFF.

\section{INTRODUCTION}

The actuality In the pathogenesis of glaucoma optical neuropathy (GON) the main role is played by the degenerative process leading to disorders of axonal transport of subcortical centers, in axons, as well as in the bodies of ganglion cells [17]. A common cause of nerve cell damage and its possible death through apoptosis is the loss of trophic support and the release of cytokines [Nesterov A.P., 2000]. Depending on the stage of glaucoma disease a part of optic nerve fibers atrophies, and the other part is in parabiosis state, which in due time allows restoring their functions under the influence of treatment (medication or 
surgical) $[6,7,8,9]$. According to a study by Vladimirov Yu.A., endothelial dysfunction and lipid metabolism disorders will lead to the deterioration of blood circulation and neurotransmission in the optic nerve, in the mechanisms of neuronal apoptosis. Lipids are structural components of membranes that serve as a form of depositing metabolic fuel reserves and play a protective role in the body $[1,2,3]$.

Undoubtedly, the optimal treatment method is to influence the pathogenetic aspects leading to GON [Flammer J., Mozaffari M., 2007].

Many foreign colleagues [14,18] positively estimate the effect of the nootropic preparation citicoline on the biosynthesis of structural phospholipids of neuron membranes in respect to visual function restoration in patients with POAG $[15,19,24]$. Citicoline is an intermediate metabolite in the synthesis of phosphatidylcholine, one of the main structural components of cell membranes. Being a precursor of ultrastructural components of cell membrane (mainly phospholipids) and having a wide spectrum of action, it restores damaged cell membranes $[16,22,23]$. Preventing the excessive formation of free radicals, citicoline inhibits the action of phospholipases, and also prevents cell death, affecting apoptosis mechanisms [20,21,25]. Vitolin forte, eye drops ("Aseptica", Uzbekistan), which contain citicoline, appeared on pharmaceutical market Figure 1. of Uzbekistan, that led us to conduct comparative study of effectiveness of neuroprotective action of the medications with POAG.

Objective: to evaluate the efficacy of complex treatment of patients with POAG according to the data of electrophysiological parameters of the central part of the retina and optic nerve.

\section{MATERIALS AND METHODS}

Clinical material was collected on the basis of the Republican Specialized Scientific and Practical Medical Center for Eye Microsurgery. We examined 60 patients (120 eyes) with POAG I, II and III stages with stabilized IOP level. Patients were divided into 2 groups depending on the type of treatment performed: the 1st group (control) - 30 patients (60 eyes) with POUG to whom the medication OMK-2 ("Sofarma", Italy) was administered 3 times a day, in the 2nd group (main) - 30 patients (60 eyes) were prescribed Vitolin forte ("Aseptica", Uzbekistan) 3 times a day. The duration of application of the medicines was 1 month. The main active ingredients of the drugs are: citicoline, cyancobolamine and sodium hyaluronate. Patients ranged in age from 40 to 78 years, with an average age of $62.6 \pm 3.5$ years, prevailing over middle-aged individuals. Both groups were comparable in age, sex and stage of disease.

\section{Distribution of eyes with POAG in the study groups on the basis of disease Stage}




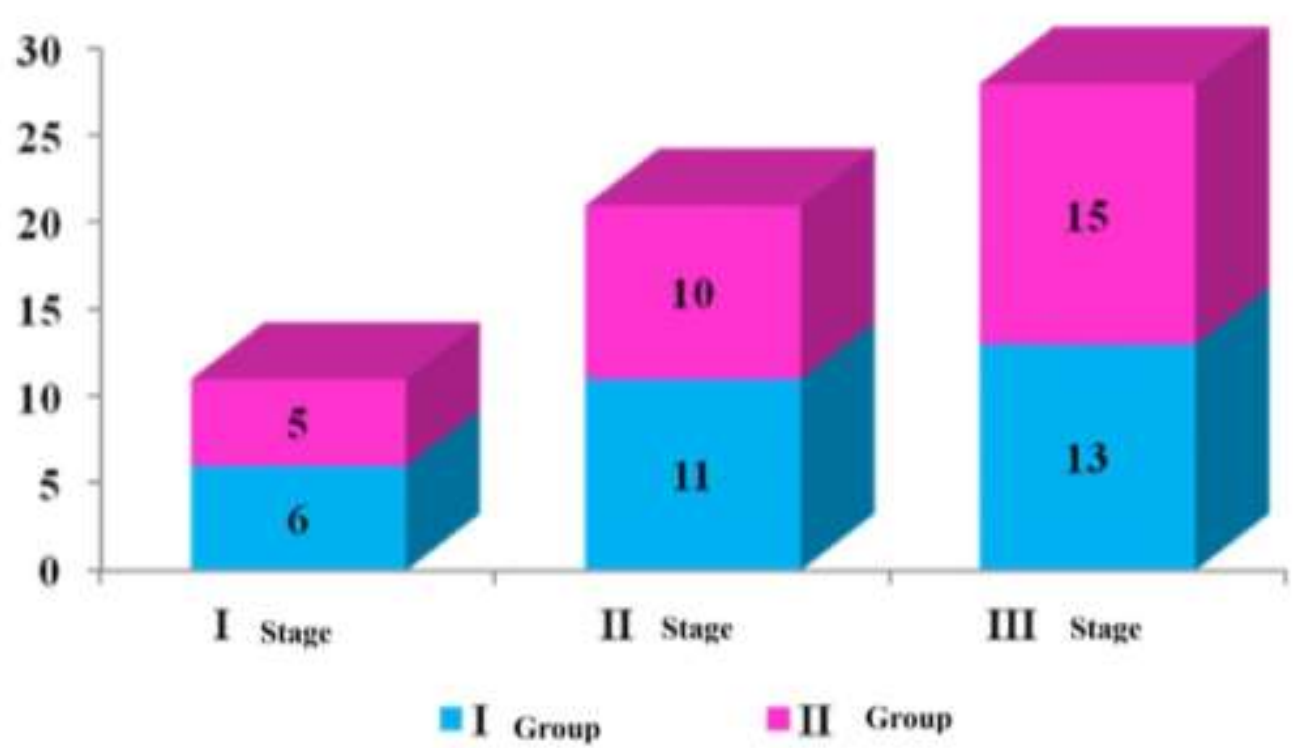

All the patients were examined using generally accepted ophthalmological methods; in particular, visometry with the best correction, biomicroscopy, gonioscopy, perimetry, tonometry, and also the critical flicker-fusion frequency (CFF) was examined on the device "Sveto-Test" by "Okulus". The CFF study was carried out by light-stimulation of photoreceptors using built-in green, blue and red light-emitting diodes. The frequency of pulsating light up to $60-80 \mathrm{~Hz}$ is perceived by human eye as visible, and over 80 to $300 \mathrm{~Hz}$ as a part of the light invisible to the human eye $[11,12]$. During the study, pulses of green, blue and red light were applied separately to each eye of the subject. The frequency was gradually increased from $1-80 \mathrm{~Hz}$ to the complete fusion of flickers [10]. The results were statistically processed with standard methods of variation statistics applying $t$ Student's criterion for evaluating the reliability of differences by using the "Statgraphics" Microsoft Excel 2007 software on Intel's Pentium Core 2 Duo computer.

\section{RESULTS AND DISCUSSION}

In all groups, the CFF indicators in the $\mathrm{Hz}$ for green light are higher relative to blue and red. This phenomenon can be explained by the fact that red-sensitive cones are concentrated in the central fossa of the retina, and greensensitive ones in the paracentral region [4].

The obtained results of the CFF in dynamics are presented in Table 1, from which it can be seen that in patients with POAG in the control group there was a significant increase of CFF index by $14,4 \%$ on the average (before treatment - 32,6 $\pm 0,7$, after treatment $37,3 \pm 0,8)$ at the I stage, at stage II by $13.8 \%$ (from $27.5 \pm 0.17$ to $31.3 \pm 0.3$ ) and by $13.7 \%$ - at stage III (before treatment $-20.40 \pm 0.63$, after treatment $-23.2 \pm 0.63$ ), while the $\mathrm{Hz}$ range in the main group increased by $13.3 \%$ at the initial stage of POAG, at a developed stage $-13.0 \%$ and by $12.7 \%$ at a far advanced stage. The dynamics of CFF indices testifies to reliably higher functional activation of retinal ganglion cells and their axons in patients of both groups after our treatment. 
Table 1.

Dynamics of changes in CFF indices $(\mathrm{Hz})$ with POAG under the influence of neuroprotective treatment

\begin{tabular}{|c|c|c|c|c|c|c|c|}
\hline \multirow{3}{*}{\multicolumn{2}{|c|}{$\begin{array}{c}\text { POAG stages by } \\
\text { group }\end{array}$}} & \multicolumn{6}{|c|}{ Variation range of $\mathrm{CFF}(\mathrm{Hz})$} \\
\hline & & \multicolumn{2}{|c|}{ Green color } & \multicolumn{2}{|c|}{ Blue color } & \multicolumn{2}{|c|}{ Red color } \\
\hline & & $\begin{array}{c}\text { Before } \\
\text { treatment }\end{array}$ & $\begin{array}{c}\text { After } \\
\text { treatment }\end{array}$ & $\begin{array}{c}\text { Before } \\
\text { treatment }\end{array}$ & $\begin{array}{c}\text { After } \\
\text { treatment }\end{array}$ & $\begin{array}{c}\text { Before } \\
\text { treatment }\end{array}$ & $\begin{array}{c}\text { After } \\
\text { treatment }\end{array}$ \\
\hline \multirow{2}{*}{$\begin{array}{c}\text { I } \\
\text { stage }\end{array}$} & Group 1 & $36,4 \pm 0,6$ & $41,4 \pm 0,9$ & $30,2 \pm 0,8$ & $34,3 \pm 0,9$ & $31,3 \pm 0,7$ & $36,2 \pm 0,5$ \\
\hline & Group 2 & $36,6 \pm 0,3$ & $41,5 \pm 0,6$ & $30,2 \pm 0,8$ & $33,9 \pm 0,7$ & $31,6 \pm 0,5$ & $36,1 \pm 0,4$ \\
\hline \multirow[b]{2}{*}{$\begin{array}{c}\text { II } \\
\text { stage }\end{array}$} & Group 1 & $30,1 \pm 0,2$ & $34,5 \pm 0,3$ & $25,6 \pm 0,2$ & $28,7 \pm 0,1$ & $26,7 \pm 0,1$ & $30,8 \pm 0,5$ \\
\hline & Group 2 & $29,9 \pm 0,1$ & $33,9 \pm 0,4$ & $24,9 \pm 0,4$ & $27,9 \pm 0,9$ & $25,9 \pm 0,8$ & $29,5 \pm 0,9$ \\
\hline \multirow{2}{*}{$\begin{array}{c}\text { III } \\
\text { stage }\end{array}$} & Group 1 & $22,9 \pm 0,4$ & $25,1 \pm 0,8$ & $18,8 \pm 0,8$ & $21,9 \pm 0,5$ & $19,8 \pm 0,7$ & $22,6 \pm 0,6$ \\
\hline & Group 2 & $22,3 \pm 0,5$ & $24,8 \pm 0,9$ & $18,6 \pm 0,7$ & $21,1 \pm 0,1$ & $19,7 \pm 0,6$ & $22,4 \pm 0,9$ \\
\hline
\end{tabular}

It was found that the prescription neuroprotective therapy at the initial stage in patients with POAG increases and maintains the electrical sensitivity of nerve fibers more and for longer than in other stages of the disease, preventing the progression of POAG. This indicates less damage to the nerve cell and its possible death by apoptosis in the early stages. It should be noted that a higher efficacy of the medications in terms of CFF was found in patients in the control group compared to the main group, however, no reliable difference between them was found. Thus, it can be concluded that the use of OMK-2 and Vitolin forte preparations containing citicoline in the complex treatment of POAG in all stages, due to the neuroprotective action, increases the CFF values with different color impulses, which 
indicates a greater degree of visual analyzer activation

\section{CONCLUSION}

1. The obtained results of the CFF parameters indicate a rather high clinical efficacy of the OMK-2 and Vitolin forte preparations in the complex treatment of POAG patients with a compensated IOP level.

2. A significant increase in the electrophysiological parameters of the central part of the retina of the eye and optic nerve in patients with POAG allows recommending new domestic preparation Vitolin forte as an effective background neuroprotective therapy.

\section{REFERENCES}

1. Boldyrev A.A. Vvedenie v membranologiyu [Introduction to Membraneology]. Moscow: Izdatelstvo MGU [MSU Publishing House], 1990; p. 208. [In Russian]

2. Burlakova Ye.B., Kerimov R.F. Vzaimosvyaz mezhdy soderzhaniyem prirodnikh antioksidantov i vyazkostyu lipidov $v$ membranakh organell $v$ norme [The relationship between the content of natural antioxidants and the viscosity of lipids in the membranes of organelles is normal] // Bullyetin eksperimentalnoy biologii, meditsina [Bulletin of experimental biology, medicine]. 1986. No. 4. P. 431-433. [In Russian]

3. Vladimirov Yu.A., Olenev V.I., Suslova T.B. POL i yego deystviye na biologicheskiye membrani [Sex and its effect on biological membranes] //
Biophysics. Molyekulyarnaya patologiya membrannikh struktur [Molecular pathology of membrane structures]. Moscow, 1975. Vol. 5. P. 53-59. [In Russian]

4. Volkov A.S., Morozova L.V. KChSM kak metod psikhofiziologicheskogo issledovaniya analizatora [CFF as a method of psychophysiological study of the visual analyzer]. Mejzdunarodniy studencheskiy nauchniy vestnik [International Student Scientific Newsletter]. - 2015. - No. 2 (Part 3). P. 310-312. [In Russian]

5. Ye.I. Dmitriyeva, T.Yu. Kim, D.I. Konkina, N.O. Pytel. Sovremenniy vzglyad na etiopatogenez pervichnoy otkritougolnoy glaukomi [A modern view of the etiopathogenesis of primary open-angle glaucoma]. "Meditsina i obrazovaniye $v$ Sibiri" [Medicine and education in Siberia] (ISSN 1995-0020). No. 3 - 2014. [In Russian]

6. Kurysheva N.I., Parshunina O.A. Opticheskaya kogerentnaya tomografiya v diagnostike glaukomoy optikoneyropatii [Optical coherence tomography in the diagnosis of glaucoma optic neuropathy]. Part 1. Natsionalniy jurnal glaukoma [National Glaucoma Journal] 2016, Vol. 15, No. 1. P. 86-96. [In Russian]

7. Kurysheva N.I. Opticheskaya kogerentnaya tomografiya $v$ diagnostike glaukomoy optikoneyropatii [Optical coherence tomography in the diagnosis of glaucoma optic neuropathy]. Part 2. Natsionalniy jurnal glaukomi [National Glaucoma Journal] 2016, Vol. 15, No. 3. P. 60-70. [In Russian]

8. Kurysheva N.I. Rol metodov vizualizatsii diska zritelnogo nerva i sloya nervnikh volokon setchatki $v$ ranney diagnostike glaukomi [The role of imaging of the optic nerve and retinal nerve fiber layer in the 
early diagnosis of glaucoma]. Glaucoma 2007; 1:16-22. [In Russian]

9. Kurysheva N.I. Maslova Ye.V., Trubilina A.V., Lagutin M.B. Rol opticheskoy kogerentnoy tomografii $s$ funktsiey antiografii $v$ ranney diagnostike $i$ monitoringe glaukomy [The role of optical coherence tomography with angiography function in early diagnosis and monitoring of glaucoma]. Natsionalniy jurnal glaukoma [National Glaucoma Journal] 2016, Vol. 15, No. 4, p. 20-31. [In Russian]

10. Moryakina S.V., Anzorov V.A., Abumuslimov S.S., BArgayeva Kh.Sh. Opredeleniya funktsionalnogo analizatora u studentov, otlichayushikhsya po gendernim priznakam s pomoshyu svetotesta [Determining the functional state of the visual analyzer in students with different gender characteristics using the light test]. Sovremennaya nauka: Aktualniye problemy i puti ikh resheniya [Modern science: Current problems and solutions]. -2015. - No.9(22). P: 62-67. [In Russian]

11. Orudjova O.N. Optimalniy razmer stimula pribora dlya opredeleniya kriticheskoy chastoty sliyaniya melkaniy [Optimal instrument stimulus size for determining critical flicker-fusion frequency]. Tekhnicheskiye nauki [Technical Sciences]. - 2018. - No. 1 - P. 16-21. [In Russian]

12. Orudjova O.N. Shabunina N.V. O trebovaniyakh, predyavlyaemykh $\mathrm{k}$ priboram dlya opredeleniya kriticheskoy chastoty svetovykh melkaniy [On the requirements of the devices for determining the critical flicker-fusion frequency]. Nauchnoe obozreniye [Scientific Review]. Tekhnicheskiye nauki [Technical Sciences]. - 2018. - No. 5 - P. 25-29. [In Russian]
13. Surnin S.N. Kilinicheskaya otsenka effektivnosti neyromidina $v$ kompleksnom lechenii bolnykh pervichnoy glaukomoy [Clinical evaluation of neuromidine efficacy in the complex treatment of patients with primary glaucoma]. Voronezh, 2016; p. 4. [In Russian]

14. Ahmad A. Aref, MD, MBA, Anand Bhatt, Ian Conner, MD, PhD and Samuel Asanad, MD. American Academy of ophthalmology. Neuroprotection in Glaucoma. By Ian Conner, MD, PhD on April 22, 2020.

15. Cohen J.D., Drury J.H., Ostdiek J., et al. Benefits of lipid lowering on vascular reactivity in patients with coronary artery disease and average cholesterol levels: a mechanism for reducing clinical events? Am Heart J 2000; 139:734-738.

16. Gandolfi S, Marchini G, Caporossi A, et al. Cytidine 5'-Diphosphocholine (Citicoline): Evidence for a Neuroprotective Role in Glaucoma. Nutrients. 2020; 12(3).

17. Guymer C, Wood JP, Chidlow G, Casson RJ. Neuroprotection in glaucoma: recent advances and clinical translation. Clin Experiment Ophthalmol. 2019; 47(1):88105.

18. Kaur IP, Smitha R. Penetration enhancers and ocular bioadhesives: two new avenues for ophthalmic drug delivery. Drug Dev Ind Pharm. 2002 Apr; 28(4):35369. https://doi.org/10.1081/ddc-120002997 PMID: 12056529.

19. Kaushik S., Pandav S.S., Ram J. Neuroprotection in glaucoma. J Postgrad Med 2003; 49(1):90-95.

20. Lanza M, Gironi Carnevale UA, Mele L, et al. Morphological and functional evaluation of oral citicoline therapy in chronic open-angle glaucoma patients: A pilot study with a 2-year follow-up. Front. Pharmacol. 2019;10:1117. 
21. Parisi V, Centofanti $M$, Ziccardi $L$, et al. Treatment with citicoline eye drops enhances retinal function and neural conduction along the visual pathways in open angle glaucoma. Graefes Arch. Clin. Exp. Ophthalmol. 2015;253:1327-1340.

22. Parisi V, Oddone F, Roberti G, et al. Enhancement of retinal function and of neural conduction along the visual pathway induced by treatment with citicoline eye drops in liposomal formulation in open angle glaucoma: A pilot electrofunctional study. Adv. Ther. 2019; 36:987-996.

23. Roberti G, Tanga L, Parisi V, et al. A preliminary study of the neuroprotective role of citicoline eye drops in glaucomatous optic neuropathy. Indian J. Ophthalmol. 2014; 62:549-553.

24. Schmidl D., Boltz A., Kaya S., et al. Role of nitric oxide in optic nerve head blood flow regulation during isometric exercise in healthy humans. Invest Ophthalmol Vis Sci 2013; 54(3): 1964-1970.

25. Secades JJ, Lorenzo JL. Citicoline: pharmacological and clinical review, 2006 update. Methods Find Exp Clin Pharmacol. 2006 Sep; 28 Suppl B:1-56. PMID: 17171187 